\title{
Seismic Analysis on Mass and Stiffness Variation in RC Buildings by Numerical Modelling
}

\author{
Saugat Tiwari \\ MSc. Student (Infrastructure Engineering and \\ Management) \\ Department of Civil and Geomatics Engineering \\ Pashchimanchal Campus, IOE, Tribhuvan University \\ Pokhara, Nepal
}

\author{
Sailesh Adhikari \\ Lecturer \\ Department of Civil and Geomatics Engineering \\ Pashchimanchal Campus, IOE, Tribhuvan University \\ Pokhara, Nepal
}

\begin{abstract}
From the past earthquakes in the globe it is seen that irregular buildings are the most vulnerable during the earthquake. However irregularity cannot be avoided in most of the cases during the construction of $\mathrm{RC}$ buildings. Irregular buildings are generally proposed by architects for the sake of aesthetic beauty of the structure. So, it is necessary to determine seismic responses of buildings with irregular configurations. In this paper ten storey RC building with varying mass and stiffness parameter is considered and numerically modelled in SAP 2000. Response spectrum analysis is used to modelled the building. Total four number of models are prepared with different loading and load combinations with seismic zone $V$ and medium type of soil. The modelling of building is done as per IS 1893 (Part 1):2016 and IS 456:2000. For given structure, applied loads includes dead load, live load and earthquake load, the building is assigned the respective loading and load combinations. The building is modelled on SAP2000 and the structural parameters like displacement, base shear, storey drift and reinforcement bar requirement is calculated. It is found that, with the increase in the column stiffness the axial forces in columns and base shear of the building increases. Similarly top story displacement is more in the buildings where there is more mass on the top storey resulting in increase of the lateral force. This study concluded that frames having irregular floors with larger floor height are critical than the building of same floor height. Also it is observed that rebar requirement and displacement of the building is less if there is stiffness and mass variation near the base of the building rather than the top of the building.
\end{abstract}

Keywords- RC Building, Irregularities, Earthquake, Stiffness, Mass

\section{INTRODUCTION}

During an earthquake, failure of structure starts at points of weakness. Generally weakness is result of the non-regular geometry, mass discontinuity and stiffness of structure. The structures having these parameters are termed as irregular structures. Past earthquakes have revealed that the major reason for failure of structures is due to irregular configuration. Mass and stiffness are two basic parameters to evaluate the dynamic response of a structural system under vibratory motion. High rise multistoried buildings are behaved differently depending upon the various parameters like massstiffness distribution, foundation types and soil conditions. The dynamic behavior of a building, when an earthquake is shaking, depends on the variation of the parameters of the building structure that is its mass, stiffness and damping value.
Several research has been completed to study the seismic behavior of the building for varying structural parameters. The study on the structural parameters by varying mass and stiffness in 20 storey building by placing the swimming pool in the different floor level revealed that the irregular structure is more critical than the regular structure during the earthquake [1]. Pushover analysis of building by introducing soft storey shows that, drift demands in the upper stories are much more sensitive to irregularities in the lower stories, than the response of lower stories is affected by irregularities in the upper stories [2]. Seismic effect on the building by considering the setback effect concludes that the stiffness of the building decreases as the setback increases [3]. The infill materials in the frame structure is determining factor than the soft storey for the building response during seismic load [4]. In the earthquake prone zones, it is always safe to construct a high-rise building with nearly uniform floor mass and storey stiffness [5]. Linear and nonlinear dynamic analyses of engineered buildings exhibit that most structures performed well when subjected to the design earthquake, also uniformity in mass and stiffness produces optimum resistance against the seismic forces [6]. According to IS 1893(Part 1):2016, the irregularity in the building structures may be due to irregular distributions in their mass, strength and stiffness along the height of building. When these type of building are constructed in earthquake prone zones, the design and analysis of structure becomes complicated. IS 1893(Part 1):2016 have classified two types of irregularities i.e. plan irregularities and vertical irregularities. This paper discuss about the behavior of building, based upon the numerical modelling, by varying different types of vertical irregularities. The parameters that will be varied in the numerical modelling are mass irregularities and stiffness irregularities.

\section{NUMERICAL MODELLING USING SAP 2000}

In the present study reinforced concrete moment resisting frame building models of 10 storey is considered, RCC multi storey building is considered which is regular in shape. The top floor have less number of columns compared to the other floors. The plan of building upto $8^{\text {th }}$ storey is shown in Fig. 1 and the plan of the building on the top floor or $9^{\text {th }}$ storey is shown in Fig. 2. Fig. 3 shows the typical elevation of the building, 3D of the building is shown in Fig 4. Different building configuration is used to compare the seismic 
behavior among different configuration of building. On assigning different load and load combination there is variation on mass and stiffness on building. Stiffness variation on the model is

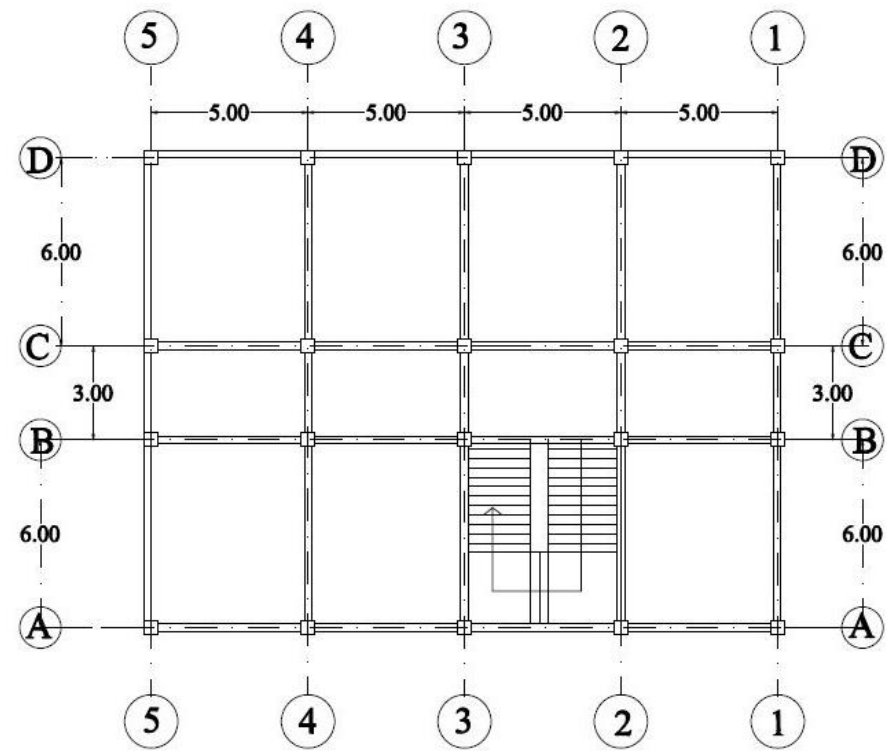

Fig. 1: Plan of the building (Ground to $8^{\text {th }}$ Storey)

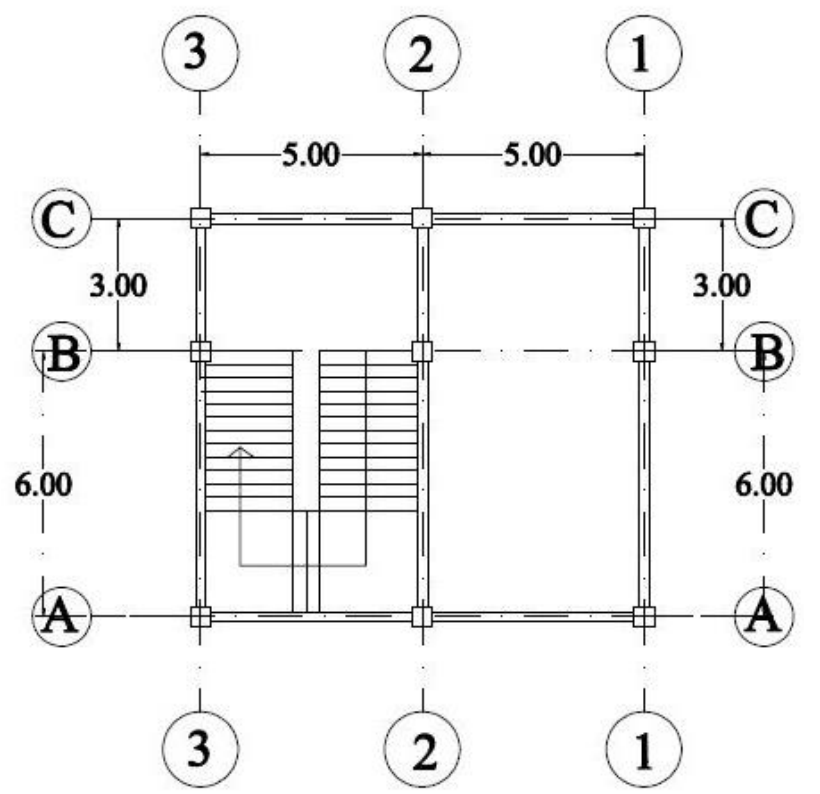

Fig. 2: Plan of the building (Top or $9^{\text {th }}$ storey)

varied by varying the column height of same section in all the model during the study. Mass variation was done as varying the load pattern on different floor. As per the variation on mass and stiffness the behavior of models such as displacement of the models, drift ratio, base shear in both $\mathrm{X}$ and $\mathrm{Y}$ direction is studied and the results are obtained. The models are having different loading criteria, which having mass irregularity and different column size for stiffness irregularity. The numerical modelling is completed using SAP 2000 , four different configurations of buildings each having 10 storey are modelled. Table 1 shows the details of the structural parameters considered in the numerical modelling. Mass irregularity in plan is introduced by applying different loads in the slab as given in Table 1. Beams and columns are modelled as the frame element while slab is modelled as a membrane element. During the modelling response-spectrum analysis is

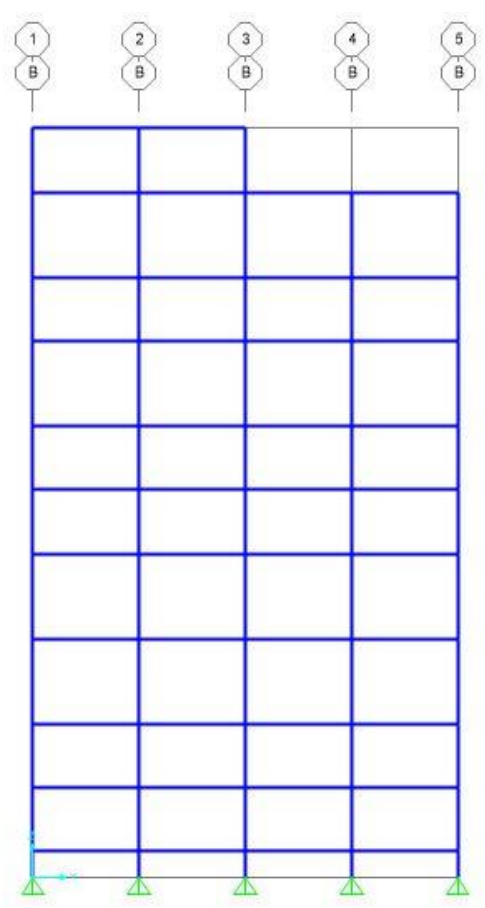

Fig. 3: Elevation of the building

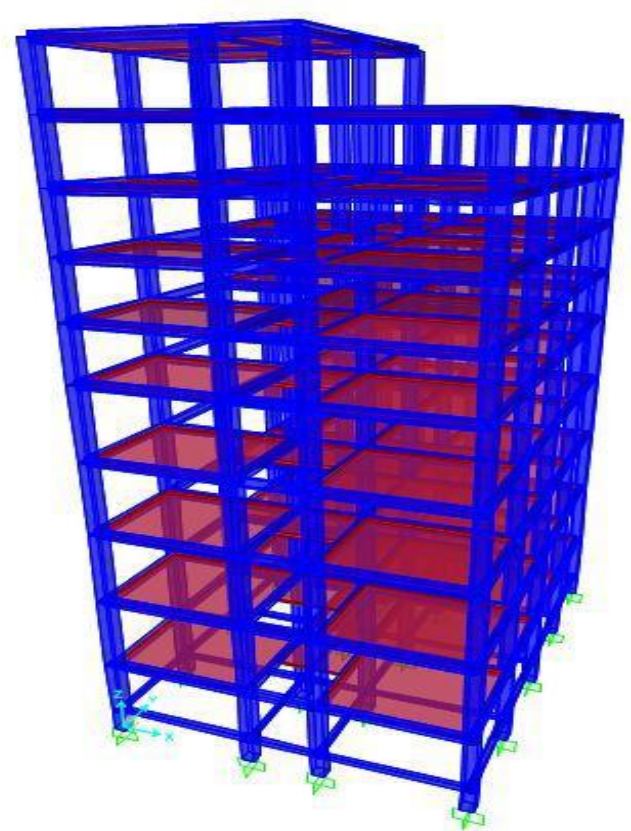

Fig. 4: 3D model of the building

opted. All the models have square column of size $550 \mathrm{~mm} \times$ $550 \mathrm{~mm}$, rectangular beam size of $230 \mathrm{~mm} \times 450 \mathrm{~mm}$ and slab of thickness of $125 \mathrm{~mm}$. The building is considered to be in seismic zone $\mathrm{V}$ with importance factor 1 . Concrete grade of M20 and reinforcement of Fe500 is assigned to all the frame members. Medium type of soil is considered in the numerical modelling. External load, internal load and parapet wall load of $5.15 \mathrm{kN} / \mathrm{m}, 5.13 \mathrm{kN} / \mathrm{m}$ and $4.8 \mathrm{kN} / \mathrm{m}$ respectively is applied to the building. Floor finish of $1 \mathrm{kN} / \mathrm{m}^{2}$ was applied in all the slab of the building. Floor height of $3 \mathrm{~m}$ and $4 \mathrm{~m}$ are 
introduced for stiffness irregularity and live load of $6 \mathrm{kN} / \mathrm{m}^{2}$ and $4 \mathrm{kN} / \mathrm{m}^{2}$ are imposed for mass irregularity.

Table 1: Structural loads and parameters of RC building model

\begin{tabular}{|c|c|c|c|c|}
\hline \\
\hline Model & 1 & 2 & 3 & 4 \\
\hline $\begin{array}{l}\text { Floor Height } \\
(4 \mathrm{~m})\end{array}$ & $\begin{array}{l}\text { Ground } \\
\text { Floor }\end{array}$ & $\begin{array}{l}1^{\text {st }}, 2^{\text {nd }}, 3^{\text {rd }} \\
\text { and } 4^{\text {th }} \text { floors }\end{array}$ & $\begin{array}{l}2^{\text {nd }}, 3^{\text {rd }}, 7^{\text {th }} \\
\text { and } 9^{\text {th }} \\
\text { floors }\end{array}$ & $\begin{array}{l}4^{\text {th }}, 5^{\text {th }}, 6^{\text {th }} \\
\text { and } 8^{\text {th }} \text { floors }\end{array}$ \\
\hline $\begin{array}{c}\text { Floor Height } \\
(3 \mathrm{~m})\end{array}$ & $\begin{array}{l}1^{\text {st }} \text { floor to } \\
\text { Top floors }\end{array}$ & $\begin{array}{l}\text { Ground, } 5^{\text {th }}, \\
6^{\text {th }}, 7^{\text {th }}, 8^{\text {th }} \\
\text { and } 9^{\text {th }} \text { floors }\end{array}$ & $\begin{array}{l}\text { Ground, } 1^{\text {st }}, \\
4^{\text {th }}, 5^{\text {th }}, 6^{\text {th }} \\
\text { and } 8^{\text {th }} \text { floors }\end{array}$ & $\begin{array}{l}\text { Ground, } 1^{\text {st }}, \\
2^{\text {nd }}, 3^{\text {rd }}, 7^{\text {th }}, \\
\text { and } 9^{\text {th }} \text { floors }\end{array}$ \\
\hline $\begin{array}{l}\text { Live Load } \\
\left(6 \mathrm{kN} / \mathrm{m}^{2}\right)\end{array}$ & $\begin{array}{l}\text { Bottom } 4 \\
\text { floors }\end{array}$ & Top 3 floors & $\begin{array}{c}2^{\text {nd }}, 3^{\text {rd }}, 7^{\text {th }} \\
\text { and } 9^{\text {th }}\end{array}$ & $\begin{array}{c}4^{\text {th }}, 5^{\text {th }} 6^{\text {th }} \text { and } \\
8^{\text {th }} \text { floors }\end{array}$ \\
\hline $\begin{array}{l}\text { Live Load } \\
\left(4 \mathrm{kN} / \mathrm{m}^{2}\right)\end{array}$ & $\begin{array}{c}\text { Other than } \\
\text { bottom } 4 \\
\text { floors }\end{array}$ & $\begin{array}{l}\text { Other than } \\
\text { top } 3 \text { floors }\end{array}$ & $\begin{array}{l}\text { Ground, } 1^{\text {st }}, \\
4^{\text {th }}, 5^{\text {th }}, 6^{\text {th }} \\
\text { and } 8^{\text {th }} \text { floors }\end{array}$ & $\begin{array}{l}\text { Ground, } 1^{\text {st }} \text {, } \\
2^{\text {nd }}, 3^{\text {rd }}, 7^{\text {th }}, \\
\text { and } 9^{\text {th }} \text { floors }\end{array}$ \\
\hline $\begin{array}{l}\text { Roof Live } \\
1.5 \mathrm{kN} / \mathrm{m}^{2}\end{array}$ & \multicolumn{4}{|c|}{ All top part of $9^{\text {th }}$ storey and $50 \%$ of roof area on $8^{\text {th }}$ storey } \\
\hline $\begin{array}{c}\text { Time Period } \\
(\mathrm{sec})\end{array}$ & 1.51 & 1.84 & 1.77 & 1.75 \\
\hline $\begin{array}{c}\text { Seismic } \\
\text { Weight }(k N)\end{array}$ & 30585.33 & 30685.20 & 33491.429 & 28715.36 \\
\hline
\end{tabular}

\section{RESULTS AND DISCUSSIONS}

The four models of the RC buildings are analyzed and the data are extracted in the form of drift, displacement, stiffness variation, mass variation and the reinforcement bar requirement. Different building models exhibits different types of behavior due to the irregularities. The results of the each parameters are discussed below.

\section{A. Stiffness}

Stiffness of all the models in both $\mathrm{X}$ and $\mathrm{Y}$ direction is as shown in Fig 5 and Fig. 6 respectively. The figure shows different stiffness of model in different floor level. Stiffness is inversely proportional to the length of the column, thus for as varying floor height there is variation in stiffness of the RC building models. In model 1 height of column on ground floor is $4 \mathrm{~m}$, so $1^{\text {st }}$ storey have less stiffness with respect to other models. Similarly model 4 have $4 \mathrm{~m}$ height of column in $5^{\text {th }}$ storey, thus there it has less stiffness compared to other models. In each floor altering the column length will introduce variation of stiffness on floor. The high stiffness in lower storey doesn't significantly affect the stiffness of the buildings, whereas stiffness in the higher floor levels will be dominant to govern the stiffness of the building.

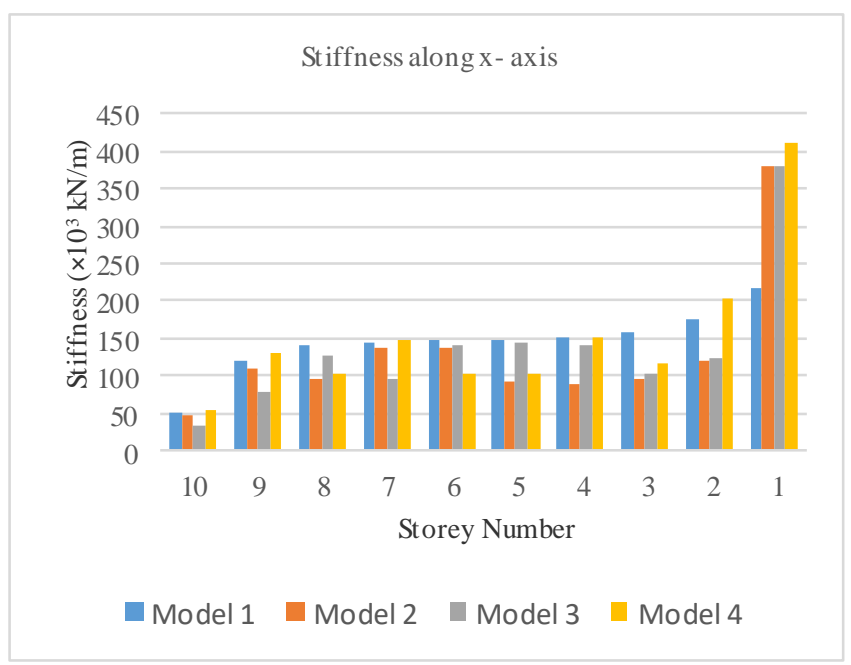

Fig. 5: Stiffness along $X$ axis

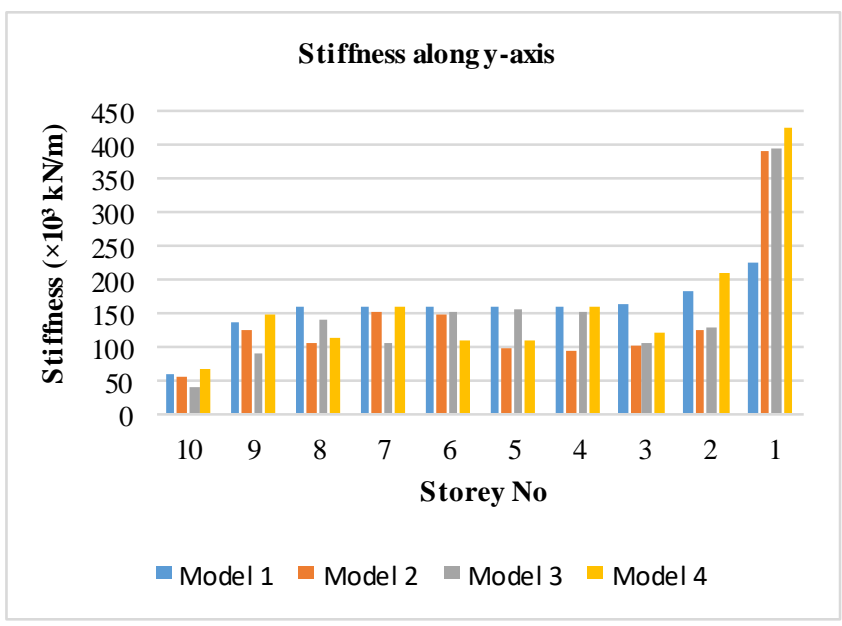

Fig. 6: Stiffness along Y axis

\section{B. Mass Variation}

Table 2 shows the mass of different models, all the models have different mass on different floor level. Mass variation on models done by changing the live load on different floor. In model 1 there is increase in load on $1^{\text {st }}, 2^{\text {nd }}$ and $3^{\text {rd }}$ floor compared to other floor so there is variation on mass. In model 2 top three floor have increase in floor load so there is variation on mass. In model 3 there is variation on mass on $2^{\text {nd }}, 3^{\text {rd }}, 7^{\text {th }}, 9^{\text {th }}$ floor. In model 4 there is variation on mass on $4^{\text {th }}, 5^{\text {th }}, 6^{\text {th }}$ and $8^{\text {th }}$ floor and other floor of same live load. There is variation on mass on same floor level it is due to variable live load partition wall load. Model 1 and model 2 have same loads on plan on $6^{\text {th }}$ storey similarly model 3 and model 4 have same value of loads on plan on $6^{\text {th }}$ storey, this induces the variation of mass on models. The mass variation in the lower floor is less critical than the mass variation in the upper floors.

\section{Base Shear}

Fig. 7 shows the base shear of models as there is variation on mass and stiffness on different models in both $\mathrm{X}$ and $\mathrm{Y}$ directions. Model 1 have maximum base shear and model 2 have less base shear among the various model considered in the study. As time period increases base shear of the model decreases, thus model 1 have maximum base shear value as it 
have less time period than other models. Base shear help to estimate the maximum expected lateral force which will occur due to ground motion at the base of the structure. The presence of max base shear indicates the presence of maximum lateral forces which makes the building unsafe. Higher floor height in the ground floor increases the base shear, higher floor height in the top level doesn't influence much in base shear value.

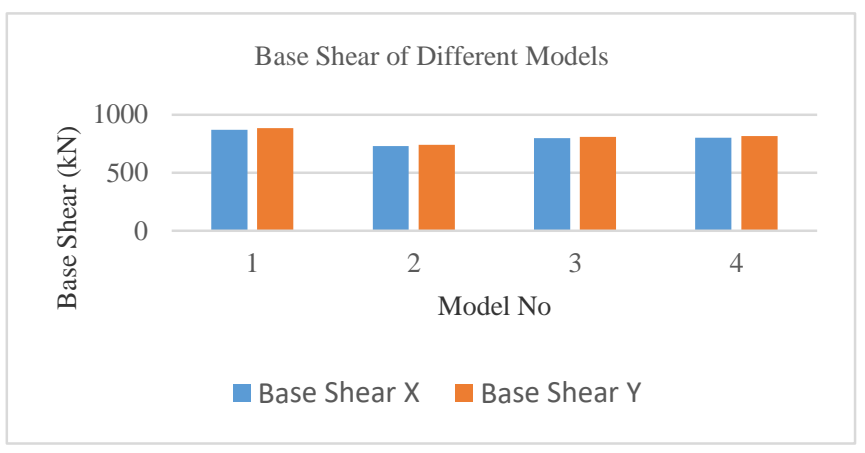

Fig. 7: Base Shear of Models

Table 2: Mass variations of the models

\begin{tabular}{|c|c|c|c|c|}
\hline Storey & Model 1 & Model 2 & Model 3 & Model 4 \\
\hline 10 & 87.03 & 87.03 & 95.21 & 87.03 \\
\hline 9 & 266.43 & 266.43 & 300.63 & 266.43 \\
\hline 8 & 315.43 & 358.71 & 323.14 & 323.14 \\
\hline 7 & 315.43 & 357.14 & 358.71 & 323.14 \\
\hline 6 & 315.43 & 351.00 & 323.14 & 323.14 \\
\hline 5 & 315.43 & 323.14 & 315.43 & 330.85 \\
\hline 4 & 351.00 & 330.85 & 315.43 & 323.14 \\
\hline 3 & 349.43 & 330.85 & 357.14 & 323.14 \\
\hline 2 & 349.43 & 330.85 & 366.42 & 323.14 \\
\hline 1 & 346.74 & 312.73 & 312.73 & 305.03 \\
\hline Base & 30.84 & 23.13 & 23.13 & 23.13 \\
\hline
\end{tabular}

\section{Shear, displacements and drift of the buildings}

Table 3 shows the variation of the base shear, maximum displacement and maximum storey drift for the four different type of models. Base shear is maximum in model 1, maximum displacement is in model 2 and maximum drift is in model 2 and 3. It is observed that as we increase the column stiffness, axial forces in columns and base shear increases. Similarly top story displacement is more in the buildings where there is more mass on the top storey which in result increases the lateral force of the building models.

\section{E. Maximum Reinforcement}

Fig. 8 shows the maximum reinforcement area required on models. The irregularities in the buildings is the major cause of the increase in the reinforcement of the structure. The irregularities pattern due to variation of mass and stiffness in the buildings is the determining factor for the reinforcement demand. The buildings having mass and stiffness variation in higher floor demands more rebar than the buildings having mass and stiffness variation in the lower floors. Model 1 have mass variation and stiffness variation near the base of the building whereas other model have variation in the upper floors, so there is maximum rebar required on other models.

\section{F. Displacements of the buildings}

Table 4 shows the displacements of the variation of the base shear, maximum displacement and maximum storey drift for the four different type of models. It is seen that model 2 have highest value of displacement in $\mathrm{x}$ axis and $\mathrm{y}$ axis, whereas model 1 has lowest value of displacement. Rate of change in displacement is almost uniform in nature in model 1 compared to the other models. Model 3 has the highest value of variation in stiffness and mass whereas model 1 has uniform variation in the vertical plane.

Table 3: Shear, displacements and drift of the buildings

\begin{tabular}{|c|c|c|c|c|c|c|}
\hline Model & \multicolumn{2}{|c|}{$\begin{array}{c}\text { Base Shear } \\
(\mathrm{kN})\end{array}$} & \multicolumn{2}{c|}{$\begin{array}{c}\text { Max Displacement } \\
(\mathrm{mm})\end{array}$} & \multicolumn{2}{c|}{$\begin{array}{c}\text { Max Storey Drift } \\
(\%)\end{array}$} \\
\hline & \multicolumn{2}{|c|}{ Direction } & \multicolumn{2}{c|}{ Direction } & \multicolumn{2}{c|}{ Direction } \\
\hline & $\mathrm{X}$ & $\mathrm{Y}$ & $\mathrm{X}$ & $\mathrm{Y}$ & $\mathrm{X}$ & $\mathrm{Y}$ \\
\hline 1 & 870.10 & 885.93 & 48.67 & 44.13 & 0.23 & 0.22 \\
\hline 2 & 732.52 & 744.00 & 54.97 & 50.17 & 0.24 & 0.23 \\
\hline 3 & 799.37 & 812.23 & 54.35 & 49.48 & 0.24 & 0.23 \\
\hline 4 & 803.46 & 817.16 & 48.98 & 45.02 & 0.22 & 0.21 \\
\hline
\end{tabular}

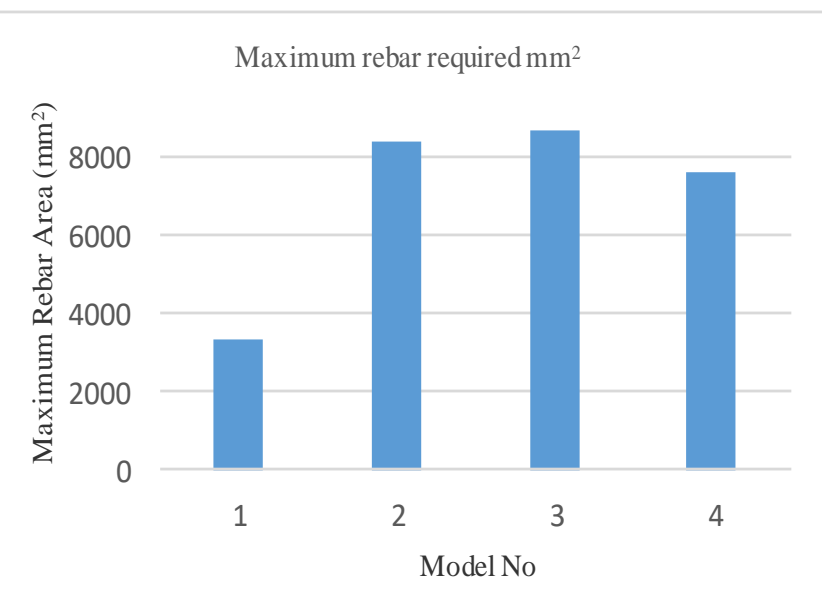

Fig. 8: Maximum amount of reinforcement area required

Table 4: Displacements of the buildings

\begin{tabular}{|c|c|c|c|c|c|c|c|c|}
\hline \multirow{3}{*}{ Storey } & \multicolumn{2}{|c|}{ Model 1 } & \multicolumn{2}{|c|}{ Model 2 } & \multicolumn{2}{c|}{ Model 3 } & \multicolumn{2}{c|}{ Model 4 } \\
\cline { 2 - 9 } & \multicolumn{2}{|c|}{ Direction } & \multicolumn{2}{c|}{ Direction } & \multicolumn{2}{c|}{ Direction } & \multicolumn{2}{c|}{ Direction } \\
\cline { 2 - 9 } & $X$ & $Y$ & $X$ & $Y$ & $X$ & $Y$ & $X$ & $Y$ \\
\hline 10 & 48.7 & 44.1 & 55.0 & 50.2 & 54.4 & 49.5 & 49.0 & 45.0 \\
\hline 9 & 46.7 & 42.6 & 53.2 & 48.8 & 51.3 & 47.0 & 47.3 & 43.7 \\
\hline 8 & 44.2 & 40.5 & 50.9 & 46.9 & 47.6 & 43.8 & 45.2 & 41.9 \\
\hline 7 & 40.8 & 37.7 & 46.5 & 43.2 & 44.0 & 40.8 & 40.8 & 38.1 \\
\hline 6 & 36.6 & 33.9 & 42.6 & 39.8 & 38.0 & 35.4 & 36.9 & 34.6 \\
\hline 5 & 31.5 & 29.4 & 37.8 & 35.5 & 33.1 & 31.0 & 30.1 & 28.4 \\
\hline 4 & 25.8 & 24.2 & 29.8 & 28.0 & 27.7 & 26.0 & 22.4 & 21.2 \\
\hline 3 & 19.4 & 18.2 & 20.5 & 19.4 & 21.4 & 20.2 & 16.6 & 15.8 \\
\hline 2 & 12.6 & 11.8 & 10.9 & 10.4 & 11.7 & 11.1 & 8.0 & 7.6 \\
\hline 1 & 5.8 & 5.5 & 2.7 & 2.6 & 2.9 & 2.8 & 2.7 & 2.6 \\
\hline Base & 0 & 0 & 0 & 0 & 0 & 0 & 0 & 0 \\
\hline
\end{tabular}

\section{CONCLUSIONS}

This study presented the various parametric study of the $\mathrm{RC}$ building with mass and stiffness irregularities. Base shear, storey displacement, storey drift, rebar required are studied 
and compared within the four different types of models. The following conclusions are obtained from the above analysis.

1. With the increase in the column stiffness, axial forces and base shear increases.

2. More mass in the top storey will induce more lateral displacements in the top which will in turn increase the lateral force of the building.

3. More mass in the lower storey will reduce the lateral displacement of the buildings but it will increase base shear and rebar requirement.

4. Irregularities should be prevented whereas in the unavoidable conditions irregularity on mass and stiffness should be introduced near the base of the building not at top.

5. Model 3 contains higher irregularities than the other models thus it has the maximum storey drift and maximum amount of rebar required.

\section{REFERENCES}

[1] A.R. More and R.S. Kale, "Study of seismic responses of multi-storied RCC building with mass irregularity \& column stiffness variation", International Journal of Engineering and Techniques, vol 3, pp. 739745,2017

[2] C. Chintanapakdee and A.K. Chopra, "Seismic response of vertically irregular frames: response history and modal pushover analyses", Journal of Structural Engineering, vol 130, pp. 1177-1185, 2004

[3] O. Sayyed, S.S. Kushwah and A. Rawat, "Seismic analysis of vertical irregular RC building with stiffness and setback irregularities", IOSR Journal of Mechanical and Civil Engineering, vol. 14, pp. 40-45, 2017

[4] P. Patil and D.B. Kulkarni, "Effect of different infill material on the seismic behavior of high rise building with soft storey", International Journal of Research in Engineering and Technology, vol 04, pp. 357364,2015

[5] S. Bhattacharya and S. Chakraborty, "Estimation of storey shear of a building with mass and stiffness variation due to seismic excitation", International Journal of Civil and Structural Engineering, vol 1, pp. 635-643, 2010

[6] S. Das, and J.M. Nau, "Seismic design aspects of vertically irregular reinforced concrete buildings", Earthquake Spectra, vol 19, pp. 455477,2003 